\title{
Virus Corona (2019-nCoV) penyebab COVID-19
}

\author{
MLE Parwanto \\ Departemen Biologi, Fakultas Kedokteran Universitas Trisakti, Indonesia \\ Email: edyparwanto@trisakti.ac.id; edy.parwanto@gmail.com
}

Wuhan, ibu kota Provinsi Hubei di China tengah, adalah provinsi ketujuh terbesar di negara itu dengan populasi 11 juta orang. Pada awal Desember 2019 seorang pasien didiagnosis menderita pneumonia yang tidak biasa. Pada 31 Desember, kantor regional Organisasi Kesehatan Dunia (WHO) di Beijing telah menerima pemberitahuan tentang sekelompok pasien dengan pneumonia yang tidak diketahui penyebabnya dari kota yang sama. ${ }^{(1)}$

Para peneliti di Institute of Virology di Wuhan telah melakukan analisis metagenomics untuk mengidentifikasi virus corona baru sebagai etiologi potensial. Mereka menyebutnya novel coronavirus 2019 (nCoV-2019).(2) Selanjutnya, Pusat Pengendalian dan Pencegahan Penyakit AS (CDC) menyebut virus corona sebagai 2019 novel coronavirus (2019-nCoV) dan sekarang penyakitnya populer dengan istilah coronavirus disease-19 (COVID-19). ${ }^{(3)}$

Virus corona termasuk superdomain biota, kingdom virus. Virus corona adalah kelompok virus terbesar dalam ordo Nidovirales. Semua virus dalam ordo Nidovirales adalah nonsegmented positive-sense RNA viruses. Virus corona termasuk dalam familia Coronaviridae, sub familia Coronavirinae, genus Betacoronavirus, subgenus Sarbecovirus. Pengelompokan virus pada awalnya dipilah ke dalam kelompokkelompok berdasarkan serologi tetapi sekarang berdasar pengelompokan filogenetik. Lebih jauh dijelaskan bahwa subgenus Sarbecovirus meliputi Bat-SL-CoV, SARS-CoV dan 2019-nCoV. Bat$S L-C o V$ awalnya ditemukan di Zhejiang, Yunan, Guizhou, Guangxi, Shaanxi dan Hubei, China. (4) Pengelompokan yang lain memperlihatkan bahwa virus corona grup beta meliputi Bat coronavirus (BcoV), Porcine hemagglutinating encephalomyelitis virus (HEV), Murine hepatitis virus (MHV), Human coronavirus 4408 ( $\mathrm{HCoV}$ -
4408), Human coronavirus OC43 (HCoV-OC43), Human coronavirus HKU1 (HCoV-HKU1), Severe acute respiratory syndrome coronavirus (SARS$\mathrm{CoV}$ ) dan Middle Eastern respiratory syndrome coronavirus (MERS-CoV). ${ }^{(5)}$

Virus corona berbentuk bulat dengan diameter sekitar $125 \mathrm{~nm}$ seperti yang digambarkan dalam penelitian menggunakan cryo-electron microscopy. ${ }^{(6)}$ Partikel virus corona mengandung empat protein struktural utama, yaitu protein $\mathrm{S}$ (spike protein) yang berbentuk seperti paku, protein $\mathrm{M}$ (membrane protein), protein $\mathrm{E}$ (envelope protein), dan protein $\mathrm{N}$ (nucleocapside protein). Protein $\mathrm{S}(\sim 150 \mathrm{kDa}),{ }^{(7)}$ protein $\mathrm{M}(\sim 25-$ $30 \mathrm{kDa}),{ }^{(8)}$ protein $\mathrm{E}(\sim 8-12 \mathrm{kDa}),{ }^{(9)}$ sedangkan protein $\mathrm{N}$ terdapat di dalam nukleokapsid. ${ }^{(7)}$

Analisis filogenetik mengungkapkan bahwa virus corona termasuk dalam subgenus Sarbecovirus dari genus Betacoronavirus, dengan panjang cabang yang relatif panjang untuk kerabat terdekat bat-SL-CoVZC45 dan bat-SL-CoVZXC21, dan secara genetik berbeda dari SARS-CoV. Khususnya, pemodelan homologi mengungkapkan bahwa virus corona memiliki struktur receptorbinding domain yang sama dengan SARS-CoV, meskipun terdapat variasi asam amino pada beberapa residu utama. Meskipun virus corona lebih dekat ke bat-SL-CoVZC45 dan bat-SLCoVZXC21 di tingkat genom keseluruhan, tetapi melalui analisis filogenetik dari receptor-binding domain ditemukan bahwa virus corona lebih dekat dengan garis keturunan SARS-CoV..$^{(10)}$ Dewasa ini WHO memberi nama severe acute respiratory syndrome coronavirus 2 (SARS-CoV-2) yang menjadi penyebab penyakit COVID-19. ${ }^{(11)}$

\section{REFERENSI}

1. Paules CI, Marston HD, Fauci AS. Coronavirus Infections-More Than Just the Common Cold. JAMA. 2020;323(8):707-708. doi: 10.1001/ jama.2020.0757 
2. Zhou P, Yang $X$, Wang $X$, et al. A pneumonia outbreak associated with a new coronavirus of probable bat origin. Nature. 579, 270-273 (2020). doi: 10.1038/s41586-020-2012-7

3. Centers for Disease Control and Prevention. Coronavirus (COVID-19) [Internet]. [2020] [cited 2020 Feb 2]. Available from: https:/www. cdc.gov/coronavirus/about/index.html

4. Fehr AR and Perlman S. Coronaviruses: An Overview of Their Replication and Pathogenesis. Methods Mol Biol. 2015;1282:1-23. doi: 10.1007/978-1-4939-2438-7 1

5. Schoeman D and Fielding BC. Coronavirus envelope protein: current knowledge. Virol J. 2019;16:69. doi: 10.1186/s12985-019-1182-0

6. Barcena M, Oostergetel GT, Bartelink W, et al. Cryo-electron tomography of mouse hepatitis virus: Insights into the structure of the coronavirion. Proc Natl Acad Sci U S A. 2009;106(2):582-587. doi: 10.1073/pnas.0805270106 PubMed PMID: 19124777

7. Beniac DR, Andonov A, Grudeski E, et al. Architecture of the SARS coronavirus prefusion spike. Nat Struct Mol Biol. 2006;13(8):751-752. doi: $10.1038 /$ nsmb1123

8. Armstrong J, Niemann H, Smeekens S, et al. Sequence and topology of a model intracellular membrane protein, E1 glycoprotein, from a coronavirus. Nature. 1984; 308(5961):751-752. doi: 10.1038/308751a0 PubMed PMID: 6325918

9. Godet M, L'Haridon R, Vautherot JF, et al. TGEV corona virus ORF4 encodes a membrane protein that is incorporated into virions. Virology. 1992;188(2):666-675. doi: 10.1016/00426822(92)90521-p PubMed PMID: 1316677

10. Lu R, Zhao X, Li J, et al. Genomic characterisation and epidemiology of 2019 novel coronavirus: implications for virus origins and receptor binding. The Lancet. 2020;395(10224):P565-574. doi: 10.1016/S0140-6736(20)30251-8

11. World Health Organization. Naming the coronavirus disease (COVID-19) and the virus that causes it [Internet]. [2020] - [cited 2020 Mar 17] Available from: https://www.who.int/emergencies/ diseases/novel-coronavirus-2019/technicalguidance/naming-the-coronavirus-disease-(covid2019)-and-the-virus-that-causes-it. 